\title{
Make use of advanced processing technologies to sustain dairy Industry
}

\author{
D.M. CHOUDHARI, V.S. KADAM, J.N. KHEDKAR AND B.K. PAWAR
}

\begin{abstract}
The uses of advanced processing technologies discussed in with this are most effectual for inactivation of microorganism and extension of shelf-life of milk and milk products. In addition, these technologies have no harm physico-chemical, nutritional and sensory qualities of milk and milk products.
\end{abstract}

KEY WORDS : Milk, Processing, Sustainable, Technology

How TO CITE THIS PAPER : Choudhari, D.M., Kadam, V.S., Khedkar, J.N. and Pawar, B.K. (2016). Make use of advanced processing technologies to sustain dairy Industry. Res. J. Animal Hus. \& Dairy Sci., 7(1) : 56-60 : DOI: 10.15740/HAS/RJAHDS/7.1/56-60.

Address for correspondence :

V. S. Kadam, Department of Animal Science and Dairy Science, Post Graduate Institute, Mahatma Phule Krishi Vidyapeeth, Rahuri, AHMEDNAGAR (M.S.) INDIA

Associated Authors' :

D.M. Choudhari, Shramshakti College of Agriculture, Maldad, AHMEDNAGAR (M.S.) INDIA

J.N. Khedkar, Department of Animal Science and Dairy Science, Post Graduate Institute, Mahatma Phule Krishi Vidyapeeth, Rahuri, AHMEDNAGAR (M.S.) INDIA B.K. Pawar, Department of Animal Science and Dairy Science, College of Agriculture, PUNE (M.S.) INDIA 